\title{
Susceptibility of collection pear cultivars to the agent of scab pathogen Venturia pirina Aderh
}

\author{
Elena Balykina*, Olga Ivanova, Larisa Yagodinskaya, Larisa Kovalenko, and German \\ Romanov \\ The Nikitsky Botanical Gardens - National Scientific Center of the Russian Academy of Sciences, \\ Nikita village, Yalta, 298648, Republic of the Crimea
}

\begin{abstract}
The objective of the research is to study the biology of the pathogen of the scab Venturia pirina Aderh depending on the agrometeorological conditions of the pear vegetation and to assess the collection cultivars for susceptibility to the disease. The biological features of the pear scab in the western foothill agro-climatic region of the Crimea are studied. The influence of climatic conditions on the occurrence of various epidemiological types of scab manifestations on pears is estimated. As a result of the research, highly resistant cultivars were found: Zhukovka, Zaporozhskaya, Triumph of Jodoin, Vodyanistaya, Dorodnaya, Bere Shibasso, Martin Sekl, which showed moderate levels of infection spread in all years of research, with the development of the disease in the range of $0.2-1.3 \%$. Immune cultivars of pears with absolute resistance to the pathogen agent $V$. pirina, which was not affected by changes in weather conditions, were identified. These cultivars are the following: Zimovka, Trapezitsa, Chervona, Shara Bera, Seyanets Kolossa, Populyarnaya, Kurzemskaya Maslyanaya, Wonderful Italy, which can be used in breeding and ecologized protection systems when supplying with cuttings horticultural industries in the Crimea and the south of Russia.
\end{abstract}

\section{Introduction}

The foothill regions of the Crimea, especially its southwestern part, are ancient centers of horticulture, where soil and climatic conditions have developed favorably, contributing to the cultivation of valuable fruit crops, including pears. The Crimean Pomological Station was created on the initiative of N.I. Vavilov in 1937, as a source of gene pool collections of plant resources of the country. Among fruit crops, the station has created a genetic database of unique pear cultivars, the task of which is an objective assessment and selection of cultivars in the process of in-depth study according to the main indicators: high commercial and technological qualities of fruits, high productivity, adaptation to environmental stress factors, immunity to diseases and resistance to pests [1].

The priority directions in the creation of new plantings of seed crops in the Republic of the Crimea are compiled in the Horticulture Development Program for the period 20152025 [2]. Among the main crops provided for by the plans to expand the area for fruit

\footnotetext{
* Corresponding author: e balykina@mail.ru
} 
orchards, the pear (Pyrus communis) occupies a modest place (less than 36\%), despite the fact that it is a highly profitable crop (the cost is 2-3 times more expensive than apples). This situation is explained by the fact that in recent decades the pear culture has been intensively affected by pathogens of several diseases, including scab caused by the fungus Venturia pirina Aderh, anamorph of Fusicladium pirinum (Sib.) Fokl is particularly harmful $[3,4,5,6]$. The pathogens of pear scab are being studied in many countries $[7,8,9]$.

Phytosanitary control of infection in order to preserve the crop should include measures of biologized protection against phytopathogens. One of the elements of such a system is the introduction into production of immune cultivars and hybrids with complex resistance to pathogens $[10,11]$.

The infectious potential of the $V$. pirina fungus is formed on fallen leaves, which are the sources of primary scab infection. The intensity of the infection in the spring depends on the number of affected leaves in autumn. The first signs of the disease appear in the phase of mass petal fall [12]. In the optimal variant of symptoms, when during the flowering phase the surface of the leaf tissues remains moist for more than 4-6 hours, and the average daily air temperature reaches values of $18-20{ }^{\circ} \mathrm{C}$, alongside with the development of the ascigerous stage of scab, a secondary inoculate is formed - the conidial stage of $F$. pirinum pathogen agent [13].

The symptoms of the lesion on the fruits are manifested by small necrosis on the cover, which merge to form a large spot. Epiphytotic infection occurs when condensed moisture is present on the vegetative tissue of the plant for at least 48 hours. In addition to leaves and fruits, pear scab infects shoots and branches, leading to a decrease in the number of fruit buds, which affects the productivity of trees in new seasons [14].

The objective of the research is to study the biology of the agent of scab pathogen Venturia pirina Aderh, depending on the agrometeorological conditions of the pear vegetation and to evaluate the collection cultivars for susceptibility to the disease.

\section{Materials and methods}

The disease was monitored on a natural infectious background, during 2019-2021, on 31 cultivars of pear collection plantings of the Crimean Pomological Station of the Federal State Funded Institution of Science "NBG-NSC", which is located in the western foothill agro-climatic region of the Crimea, in the nature protection zone of the Belbek River valley. The object of research is a highly specialized fungus Venturia pirina Aderh, with a conidial stage of Fusicladium pirinum (Sib.) Fokl [13].

The infectious potential of the pathogen $V$. pirina was taken into account in autumn on fallen leaves. We took 2-4 samples of 20-25 leaves from a plot of 1 ha. From the first decade of March, the percentage of maturation and the time of mass emergence of ascospores were detected by analyzing infected last year's leaves under a microscope.

The cultivar susceptibility of pear trees to scab was analyzed using indicators of the prevalence and degree of development of the disease using the formula:

$$
\mathrm{X}=\frac{\sum(6 \times \mathrm{p}) \times 100}{\mathrm{n} \times 4}
$$

where $\mathrm{X}$ is the degree of development of the disease; $\mathrm{b}$ is the lesion score, $\mathrm{p}$ is the number of leaves of this score, $n$ is the total number of registered leaves, 4 is the highest lesion score. The scale for determining the degree of development of the disease: - there is no lesion; 0.1 - from 1 to $10 \%$ of the surface of the accounting body is affected; 1 - from 10 to $25 \%$ of the surface of the accounting body is affected; 2 - from 25 to $50 \%$ of the surface of the accounting body is affected; 3 - from 50 to $75 \%$ of the surface of the accounting body is affected; $4-$ over $75 \%$ of the surface of the accounting body is affected $[10,15]$. 


\section{Results and discussion}

As a result of our research, it was found that ascospore infection of pear scab begins to develop in pseudotheciums in the second half of March. It was found that the air temperature is a less significant factor in this period of infection development than the length of daylight. In the winter months of 2020 , the average daily air temperature on average did not fall below $-4^{\circ} \mathrm{C}$, but the maturation of ascospores in peritheciums began at the same time as in the colder years 2019 and 2021, when the temperature in the winter months decreased to $-15^{\circ} \mathrm{C}$.
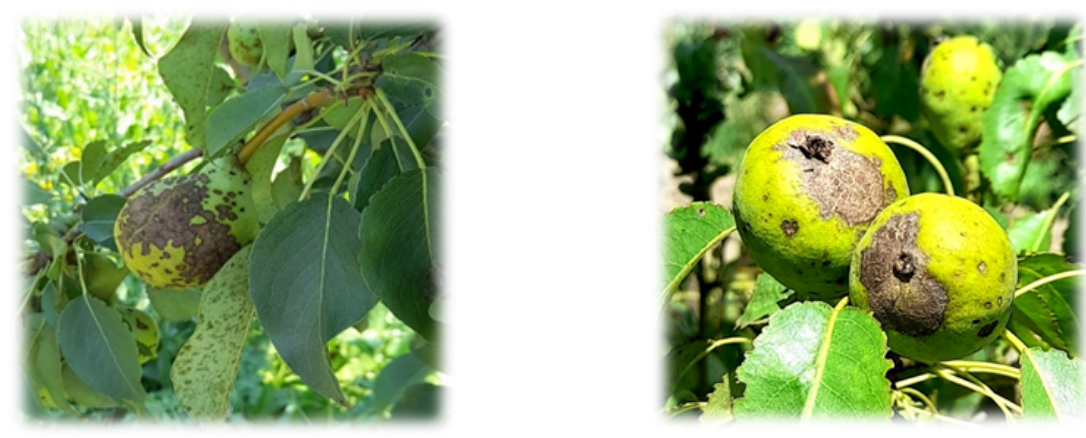

Fig. 1. Symptoms of Venturia pirina Aderh lesion on pear leaves and fruits (Original photographs)

In April, when the average daily air temperature is set at $13.5{ }^{\circ} \mathrm{C}-15.0^{\circ} \mathrm{C}$ with a relative humidity above $70 \%$, the maturation of ascospores occurs exponentially. The upper limit of the intensity of ascospore output from pseudotheciums is fixed as the temperature regime progresses in the phase of the "rosebud" of the pear, which corresponds to the first decade of May. Unlike apple scab, $V$. pirina is located on the underside of the leaves, forming small necrotic spots (Fig. 1). Pears are not protected from the penetration of the mycelium of the fungus into the pulp of the fruit, as in an apple tree. As a result of scab damage, the fruits become hard and unfit for consumption.

It was revealed that in 2019 , in the first half of the growing season, meteorological conditions were close to the average annual indicators. As a result, a moderate level of disease development was manifested and the prevalence of scab was not high (P, $32 \%)$. In May and June, the weather conditions were unstable and provoked a rapid increase in the conidial form of $F$. pirinum infection (P, $51.8 \%$ ). Thus, it was found that the parameters of humidity and temperature are less significant for summer scab spores than for ascospores and they can cause an epiphytotic type of disease development. In the conditions of the absence of chemical treatments, the intensity of lesions even on one cultivar fluctuated during the growing season: on leaves from 4.8 to $39.7 \%$ and on fruits from 20.5 to $92.0 \%$.

The lowest level of development of pear scab - depressive was recorded in the dry year 2020. In the first half of the growing season, it was only $1.5 \%$ until the second decade of May, when minor precipitation $(5.8 \mathrm{~mm})$ fell, increasing the average relative humidity (77.3\%). By the beginning of August in the second half of the growing season, there was $\mathrm{P}$ $=27.3 \%$. It was found that even against the background of moistening of the leaves, the development of scab slows down with an increase in the average daily temperature above $26{ }^{\circ} \mathrm{C}$.

The cool and humid conditions of the beginning of the growing season in 2021, with a period of moistening of the leaves for more than 12-48 hours, continued during all the months of experimental studies. During the flowering of the pear, 65\% maturation of ascospores was noted. Mass dispersion of ascospores was recorded from the phenophase of bud loosening. As a result, an epiphytotic type of disease development appeared. The 
symptoms of the lesion of $F$. pirinum conidia were clearly manifested on the fruits. The degree of development of the disease in July increased to $88 \%$.

According to the research results, the studied collection pear cultivars were differentiated by the manifestations of scab on the fruits. All cultivars classified as susceptible cannot be recommended for cultivation in the conditions of the water protection territories of the Crimea. In all the years of the study, their susceptibility to scab was high the degree of disease development was from $36.0 \%$ to $82.6 \%$ according to the average annual indicators (Table 1).

Cultivars that are tolerant to scab ( $\mathrm{R} 3.3 \%$ - 17.2\%) can be recommended for commercial growing, but the profitability of their cultivation will depend on the use of pesticides. A high degree of resistance to pear scab in the conditions of a natural infectious background was shown by 8 cultivars (Table 1$)$. The low level of infection spread (R, $0.2-$ $1.3 \%$ ) was manifested only in 2021 with extreme precipitation. Taking into account the valuable indicators of productivity and resistance to scab, these cultivars can be successfully recommended for active commercial growing in the south of Russia and in the Crimea (Table 1).

Table 1. Cultivar susceptibility to pear scab in the collection nursery of the Pomological station of the FSFIS "NBG-NSC" 2019-2021 (without treatments)

\begin{tabular}{|c|c|c|c|c|c|c|c|}
\hline \multirow[t]{3}{*}{ № } & \multirow[t]{3}{*}{ Cultivars } & \multirow[t]{2}{*}{ Origin } & \multirow[t]{2}{*}{$\begin{array}{l}\text { Terms of } \\
\text { maturity }\end{array}$} & \multicolumn{4}{|c|}{$\begin{array}{l}\text { The index of the } \\
\text { development of the disease } \\
\text { on fruits, } \mathrm{R}, \%\end{array}$} \\
\hline & & & & 2019 & 2020 & 2021 & $\begin{array}{c}\text { Average, } \\
\%\end{array}$ \\
\hline & & \multicolumn{6}{|c|}{ Vulnerable cultivars } \\
\hline 1 & Akkord & Ukraine & Winter & 72.1 & 63.7 & 85.5 & 73,7 \\
\hline 2 & Alupkinskaya & Russia & Summer & 71.2 & 64,0 & 73.2 & 69.4 \\
\hline 3 & Malgorzhatka & Ukraine & Summer & 81,3 & 78.6 & 88.0 & 82.6 \\
\hline 4 & Zamestane & Bulgaria & Summer & 77.5 & 67.4 & 81.4 & 75.4 \\
\hline 5 & $\begin{array}{l}\text { Rozovaya } \\
\text { Rannyaya }\end{array}$ & Ukraine & Summer & 64.5 & 55.2 & 72.4 & 64.0 \\
\hline 6 & Saint Germain & France & Winter & 70.7 & 61.4 & 82.1 & 71.4 \\
\hline 7 & $\begin{array}{c}\text { Rannyaya } \\
\text { Vishnyovaya }\end{array}$ & Ukraine & Summer & 54.9 & 34.1 & 43.5 & 44.2 \\
\hline & \multicolumn{7}{|c|}{ Tolerable cultivars } \\
\hline 8 & Luchistaya & Ukraine & Summer & 25.8 & 18.3 & 32.2 & 25.4 \\
\hline 9 & $\begin{array}{c}\text { Shveitsarskaya } \\
\text { Polosataya }\end{array}$ & Sweden & Winter & 25.5 & 21.1 & 27.3 & 24.6 \\
\hline 10 & Dekanka Boucher & France & Winter & 20.2 & 0 & 23.5 & 14.6 \\
\hline 11 & Grand Champion & USA & Autumn & 15.3 & 10.6 & 25.7 & 17.2 \\
\hline 12 & Korsunskaya & Ukraine & Autumn & 19.6 & 10.4 & 21.1 & 17.0 \\
\hline 13 & Eva & Italy & Autumn & 8.4 & 0 & 11.7 & 6.7 \\
\hline 14 & Zukhra & Uzbekistan & Autumn & 10.0 & 0 & 12.9 & 7.6 \\
\hline 15 & Krasnomakskaya & Ukraine & Winter & 2.8 & 0.7 & 6.5 & 3.3 \\
\hline & \multicolumn{7}{|c|}{ Resistance cultivars } \\
\hline 16 & Zhukovka & Ukraine & Autumn & 0 & 0 & 4.0 & 1.3 \\
\hline 17 & Zaporozhskaya & Ukraine & Summer & 0.5 & 0 & 3.5 & 1.3 \\
\hline 18 & Triumph of Jodoin & Belgium & Winter & 0 & 0 & 3.5 & 1.1 \\
\hline 19 & Vodyanistaya & Ukraine & Summer & 0 & 0 & 3.0 & 1.0 \\
\hline
\end{tabular}




\begin{tabular}{|c|c|c|c|c|c|c|c|}
\hline 20 & Dorodnaya & Ukraine & Summer & 0.5 & 0 & 2.5 & 1.0 \\
\hline 21 & Bere Shibasso & Ukraine & Autumn & 0 & 0 & 0.5 & 0.2 \\
\hline 22 & Martin Sekl & Italy & Summer & 0 & 0 & 0.5 & 0.2 \\
\hline 23 & Yantarnaya & Ukraine & Autumn & 0 & 0 & 0.5 & 0.2 \\
\hline & \multicolumn{7}{|c|}{ Immunity cultivars } \\
\hline 24 & Zimovka & Russia & Autumn & 0 & 0 & 0 & 0 \\
\hline 25 & Trapezitsa & Bulgaria & Summer & 0 & 0 & 0 & 0 \\
\hline 26 & Chervona & Ukraine & Summer & 0 & 0 & 0 & 0 \\
\hline 27 & Shara Bera & Ukraine & Winter & 0 & 0 & 0 & 0 \\
\hline 28 & Seyanets Kolossa & Ukraine & Summer & 0 & 0 & 0 & 0 \\
\hline 29 & Populyarnaya & Ukraine & Autumn & 0 & 0 & 0 & 0 \\
\hline 30 & $\begin{array}{c}\text { Kurzemskaya } \\
\text { Maslyanaya }\end{array}$ & Latvia & Autumn & 0 & 0 & 0 & 0 \\
\hline 31 & Wonderful Italy & Italy & Autumn & 0 & 0 & 0 & 0 \\
\hline
\end{tabular}

* Note: $\mathrm{R}$ - disease development

As a result of our research, 8 immune pear cultivars with absolute resistance to scab were found. These are cultivars: Zimovka, Trapezitsa, Chervona, Shara Bera, Seyanets Kolossa, Populyarnaya, Kurzemskaya, Wonderful Italy, which can be used in breeding, as well as for cutting and spreading seedlings in the supply of horticultural farms.

\section{Conclusion}

Thus, it is established that the conditions of the western foothill region of the Crimea, the maturation of pseudotheciums of $V$. pirina begins in the second half of March. The air temperature is a less significant factor during the development of the marsupial form of infection than the length of the daylight hours, so the maturation of ascospores in peritheciums began at the same time, both in 2020 , when the average daily air temperature in the winter months did not fall below $-4{ }^{\circ} \mathrm{C}$, and in 2019 and 2021 , when the temperature limit decreased to $-15^{\circ} \mathrm{C}$.

It was found that most pear cultivars in the conditions of a natural infectious background have a high degree of susceptibility to the pathogen $V$. pirina ( $\mathrm{R}, 36.0 \%$ 82.6\%). Less susceptible to scab (R, 3.3\% - 17.2\%) cultivars: Luchistaya, Shveitsarskaya Polosataya, Decanka Boucher, Grand Champion, Korsunskaya, Eva, Zukhra, Krasnomakskaya. A high degree of resistance to the disease was shown by 8 cultivars: Zhukovka, Zaporozhskaya, Triumph of Jodoin, Vodyanistaya, Dorodnaya, Bere Shibasso, Martin Sekl, which had a low level of infection (R, 0.2 -1.3\%) only in 2021 with extreme precipitation.

We found 8 immune cultivars of pears with absolute resistance to scab: Zimovka, Trapezitsa, Chervona, Shara Bera, Seyanets Kolossa, Populyarnaya, Kurzemskaya Maslyanaya, Wonderful Italy, which can be successfully used in the selection of promising cultivars of pears for cultivation in the Crimea and in the South of Russia.

\section{References}

1. L. Mihălescu, Z. Voșgan, O. M. Roșca, M. Marian, S. Jelea, F. Pop, A. Domuța, A.Maxim, M.Cordea, Bull. Univ. Agr. Sci. Vet. Med. Cluj-Napoca Agr, 73(2), 271 (2016) https://doi.org/10.15835/buasvmcn-agr:12414

2. E.B. Balykina, L.P. Yagodinskaya, O.V Ivanova., D.A. Korzh, Systems of protection of fruit crops from pests and diseases (Yalta, 2017). 
3. C.H. Deng, K.M. Plummer, D.A.B. Jones, C.H. Mesarich, J. Shiller, A.P. Taranto, A.J. Robinson, P. Katner, N.E. Hall, M.D. Templeton, J.K. Bowen, BMC Genomics, 18(1), 339 (2017) http://doi.org/10.1186/s12864-017-3699-1

4. J.K. Bowen, C.H. Mesarich, V.G.M. Bus, R.M. Beresford, K.M. Plummer, M.D. Templeton, Mol Plant Pathol., 12(2), 105-22 (2011) https://doi.org/10.1111/j.13643703.2010.00656.X

5. V.G.M. Bus, E.H.A. Rikkerink, V. Caffier, C. Durel, K.M. Plummer, Ann. Rev. Phytopathol., 49, 391-413 (2011) https://doi.org/10.1146/annurev-phyto-072910$\underline{095339}$

6. B. Le Cam, D.Sargent, J. Gouzy, J. Amselem, M.N. Bellanger, O. Bouchez, S. Brown, V. Caffier, M. De Garcia, R. Debuchy, G3 (Bethesda), 9(8), 2405-2414 (2019) https://doi.org/0.1534/g3.119.400047

7. I.R. Cooke, D. Jones, C. Deng, P. Faou, N.E. Hall, V. Jayachandran, M. Liem, A.P. Taranto, K.M. Plummer, S. Mathivanan, J. Prot. Res., 13(8), 3635-44 (2014) https://doi.org/10.1021/pr500176c

8. D. Sardella, A. Muscat, J.P. Brincat, R. Gatt, S. Decelis, V. Valdramidis, Int. J. Fruit Sci., 16(4), 351-337 (2016) https://doi.org/10.1080/15538362.2016.1178621

9. L. Ebrahimi, Plant Pathol. Sci., 9(1), 57-67 (2020) http://doi.org/10.29252/pps.9.1.57

10. G. Lacis, B. Lāce, M. Blukmanis, Acta Hortic., 1099, 741-747 (2015) https://doi.org/10.17660/ActaHortic.2015.1099.92

11. S, Rezviakova, A, Gurin, N.Revin, E3S Web Conf., 161, 01055 (2020) https://doi.org/10.1051/e3sconf/202016101055

12. C. Holzapfel, B. Meisel, F. Thummler, C. Leser, D. Treutter, Trees, 26, 121-129 (2012) https://doi.org/10.1007/s00468-011-0663-6

13. O.V. Ivanova, E.B. Balykina, Coll. of Sci. Works of SNBG, 148, 96-109 (2019) https://doi.org/10.25684/NBG.scbook.148.2019.10

14. Z. Borecki, Acta Agrobot., 6(1), 59-116 (2017) https://doi.org/10.5586/aa.1957.004

15. P. Benedek, T. Szabó, Z. Szabó, J. Nyéki, Int. J. Hortic. Sci., 18(2) 41-47 (2012) https://doi.org/10.31421/IJHS/18/2/1031 